\title{
STUDIES ON EXPERIMENTAL MODELS USED FOR NUTKITIUNAL AND BIOLOGICAL KESEARCH: A TECHNIQUE OF PERMANENT INSTALLATION OF KUMEN CANNULAE IN THE NIGERIAN CATTLE
}

\author{
L. A. OLADOSU \\ Department of Veterinary Medicine, \\ University of Ibadan. \\ Ibadan, Nigeria.
}

(Received 22 December 1978; accepted for publication 15 May, 1979).

\begin{abstract}
The procedure found suitable for cannulating the rumen of some indigenous breeds of cattle in Nigeria for nutritional analysis and bioassays has been described. The viability of the technique relative to others suggested for exotic ruminants, is reviewed. The anatomical location for a successful implantation in order to reduce complications to the bearest minimum has been suggested. The maintenance of the implanted cannulae for the purpose of keeping the modified experimental model in perfect health is discussed.
\end{abstract}

Key Words: Experimental Models, Nutritional Biological Research, Rumen Cannulation Cattle .

\section{INTRODUCTION}

Most nutritional and biological research on the functional and digestive activies of the bovine alimentary tract particularly the rumen will necessitate being able to obtain samples of the digesta at regular intervals. However the development of techniques in cattle for yuantitative and continous sampling of the rumen digesta without upsetting the normal physiological processes of the inimal has been very gradual. Colin 1886) was the first to use successfully the techniques of rumen fistulae in oxen (although he made no attempt to ziose the opening by any mechanical means) followed by Wester (1926), Sihalk and Amadom (1928) and Diern
Hofer in West Africa.

The purpose of this contribution is to describe the improved technique adapted for successful installation of permanent rumen cannulae in the Nigeria cattle that are used as experimental Models for nutritional and biological research.

\section{MATERIAL AND METHODS}

\section{The Cannulae:-}

The Cannulae used were essentially the same as those described by Mckenzie and Kay (1968) and Oladosu and Akpokodje (1975). They were also modified as earlier suggested by these workers in order that the cannulae could remain intact after implantation without un- 
screwing the locking nut. These cannulae ${ }^{1}$ are with bore diameters of about $6.3 \mathrm{~cm}$, a collar and a locking nut. They are rigid and unbreakable. As supplied, the fitting comprises of a flanged cylinderical body with a standard pipe thread, through which the external flange and the locking nut could run easily (Plate 4). All cannulae used for cattle were about $10 \mathrm{~cm}$ in length.Some of these cannulae were donated by the Department of Animal Science, Univer sity of Ibacian.

\section{The Animals:-}

The fistulated animals consist of the White Fulani and crosses between the Bunaji and the Congo N'Dama. One of such animals used in describing this technique (Plate $1-4$ ) was presented for rumen fistula implantation by the Department of Animal Science University of Ibadan. It was offered for fistu. lation as an experimental model for a ruminant nutritional research. The subject was admitted to the Large Animal Hospital for preoperative clinical surveillance four days before surgery. 24 hours before fistulation it received $15 \mathrm{ml}$. Tonophosphan $^{1}$ and $20 \mathrm{ml}$. combiotic ${ }^{2}$ using the intramuscular routes. Coarse fodders were withdrawn 72 hours before surgery, concentrate ration 24 hours and water 12 hours before operation. The operative site around the left paralumbar fossa was also liberally clipped and shaved 24 hours before the operation.

On the day of cannula implantation and at about 30 minutes before surgery, the subject was sedated with acepro-

1. Rigid plastisol made, Plastic and Synthetic Division, Norton Company, Akron Ohio.

1. Tonophosphan - Fabweke Hoechst AG. Franfurt (Main). Germany/Allemgne.

2. Combiotic - $250 \mathrm{mg}$ dihydrostreptomein $\mathrm{SO}$ and 200,000 I.U. Procaine Penicillin G. Pfizer Pfizer Inc., New York, U.S.A. mazine ${ }^{3}$ at a dose rate of $0.04 \mathrm{mg}$ body weight using the intramuscu route. The prepared operative site w moistened with $1 \%$ Savlon solutio scrubbed with brush, cleansed wit water and allowed to drip dry The are was wiped with lint soaked in mythy lated spirit. The subject was kept stan ding and restrained in a sueeze metallic confinement preparatory to the opera tion as shown in Plate 1 Diernhofer (1928), also employed the same technique in cattle. He however in a very crude manner, closed the fistulae with a wooden cork. Diern hofer (1928) employed a cork block instead of wood together with rubber flaps held in place by string soaked in olive oil and iodine to prevent digestion by bacteria in the rumen. These methods reviewed by Phillipson and Innes (1939) have the disadvantage that the whole stopping must be-removed each time the animal is used for experiment.

Because of these limitations and disad vantages which exist in the various early techniques in bovine rumen fistulation, the evolution of new techniques or the improvement of existing techniques as a means of gaining insigit into the rumen of cattle without serious complications, had been documented during the past years (Dougherty and Cello, 1952, Markowitz, 1954, Dougherty, 1955 Hill and Gregory, 1951, Downie, 1954, Topps. Kay and Goodall 1968). These procedures and their modifications have been established on exotic ruminants of temperate countries There are very few reports on the suitability and viability of the described techniques in the indigenous breeds of ruminants in West Africa.

Although there have been, in recent times a stream of publications derived

3. The Boots Company Ltd, nottingham England. $10 \mathrm{mg} / \mathrm{m} 1$. 
from digestibility studies on rumen fistulated West African ruminants $\mathrm{Mba}$, 1971 and Olatunji. 1971, 1973, and Olubajo and Oyenuga 1970 to mention a few), there have been very few reports concerning the fistulation techniques found suitable for the highly nervous and significantly intractable breeds of cattle

Reginoal amaesthesia of the operative site was induced with a paravertebral nerve blocks of the thirteentin thoracic, first second and third lumber nerves using $2 \%$ lignocaine $\mathrm{Hcl}^{3} .7 \mathrm{ml}$. of the anaesthetic was injected at each injection site (Plate 2) This was augmented with lineal infiltration of the proposed line of incision to desensitise paracostal ramifications of teh ventral nerves

\section{The Cannual Installation Procedure.}

The rumen was approached through a sub lumbar paracostal laparotomy which was about 2 inches caudal and parallel to the costal arch of the last rib (Plate 3) The rumen was partly outpouched through this incision and held out with two intestinal forceps at the dorsal and ventral commisures of the laparotony incision.

A continuos purse string suture of about $20 \mathrm{~cm}$ in diameter was made on the outpouched part of the intact rumen using size 3 monoflamnet nylon. An incision capable of accommodating the internal flange of the cannula to be implanted was made across the dorsolateral aspect of the rumen wall. The cannula flange was inserted into the rumen and the rumen wall drawn up the purse string The lips of the rumen wall incision were invaginated against the barrel of the cannula and the purse string suture tightened:-with four surgeon's knots. A plastic internal collar was sutured unto thie rumen between the serosal surface of the rumen and the abdominal wall as described by Ash (1962) to enable the development of adhensions between these layers and reduce the chances of leakage The extoriorization of the cannula barrel was through a secondary stab incision of the abdominal wall at about $6.3 \mathrm{~cm}$ from the transverse processes of the lumbar verte brae (Plate 4). After intraperitoneal administration of 4 megaunits of procaine penicillin $G$ the laparotomy incision was closed routinely using chromic gut No. 1 for the soft internal tissues and size 3 nylon sutures for the skin. The external flange of the cannula and the locking screw were fixed, the gauze plug was removed and the cannula opening covered with the bung (Plte 4). The operation lasted for about 60 minutes and the subject was released from the confinement and admitted in to the hospital for post operative recovery.

\section{The Post Uperatve Care:}

This consisted of administration of combiotic daily for the first 5 days and the cleaning with $1 \%$ savlon solution and application of aureomycin violet spray 48 hours after the operation and daily for one week to the sutured lin if inci sion. The patient was maintaired on good quality grass and $a d * b$ water during the period of hospitalisation. Strict hygiene of the recovery pen was maintained throughout the period ${ }^{2}$ of hospitalization. A block of rock salt (mineral lick) was provided for the animal during the period of hospitalization. This together with appropriate vitamin injection ensured good apetite and quickened recovery.

\section{RESULTS AND DISCUSSION}

The operative wounds (laparotomy and stab) healed within two weeks of 
operation after which the stitches were removed. The patients apetite in most cases appeared back to normal around the third or fourth day of operation. The subect was discharyed 3-4 weeks after surgery. After complete healing the external flange of the implanted cannula was re tightened close to the abdominal wall. Sulphenilamide powder was applied round the area of contact of the abciominal wall and the cannula barrel at re gular intervals as need arose. The post operative maintenance of the fistulated cattle was essentially the same as pre viously described, (Oladosu and Akpokodje, 1975). Daily inspection of the animal is desirable and regular cleaning of the sites arounds the cannulae witll a $15 \times 20 \mathrm{~cm}$ lint suaked in $1 \%$ Savlon solution prior to application of antibiotic powder is essential.

Experiences gained in cannulating the Nigerian cattle at the University of Ibadan shows that considerable care is needed in the siting of the cannulae. The exteriorization of the implanted rumen cannulae should be very close to the transverse process of the lumbar vertebrae at about $1 / 3 \mathrm{rd}$ up the vertebral border of the paralumbar fossa. This should be so becausi the trunk of the Bunaji cattle in seneral appears relatively narrower than those of temperate breeds of cattle with more prominent but smaller paralumbar fossa. This would enable the implanted cannula to gravitate at an angle of about $70^{\circ}$ within the rumen and reduce the chances of leakage during ruminat movements

The vulcathene type 504 waste-drain cannula fitting appeared to be better retained when implanted with very minimal leakages compared with the Ebonite or even pliable rubber cannulae. The latter together with the pressure plug 'cannulae or the pneumatic plug type as descrbed by Dougherty (1955), and Ash (1957), seemed to be often con spicuosly attended with excessive leakage when used on the Nigerian breeus of cattle.

Althougin tile perspec type cannulae have proved satisfactory in many ways and had been used with cattle in Nigeria by Akerejola at Zaria and the early visiting experts at Ibadan, they have been found in this study to have the disadvantages of being too heavy for the abdominal wall of local breecis of cattle. They are characterised with excessive leakage and are prone to dehiscence and total rejection of the implanted cannulac.

The brass cone used for cannulae exteriorization was patterned after the type used and described by Brown, Armstrons and Macrae (1968). It was designed by the author at Ibadan and prepared at the University s Mechanical work shop using a 6 long cyclinderical rod of $25 \mathrm{~cm}$ diameter The use of this brass cone has quickened theoperation time and reduced the stress on the sub ject and the surgeon.

\section{ACKNOWLEDGEVENT}

1 wish to tinank thie Sanate of the University of Ibadan for grants in support of this work and the InterUniversity Council for Higher Education overseas for a 3 -montin staff Develop ment award in $U$. $K$ during which time a comparative study of the metiod described was carried out.

I am also grateful to Professor D H. Hill Dean of the Faculty of Veterinary Medicine Ibadan University for effectined liason in the United Kingdom. Thanks are alsc due to Drs J. U. Akpokodje and A. U. Mba for their assistances and encouragements, Professor D G. Armstrons of tite University of NewcastleUpon-Tyne and Dr. R N B Kay, Head 


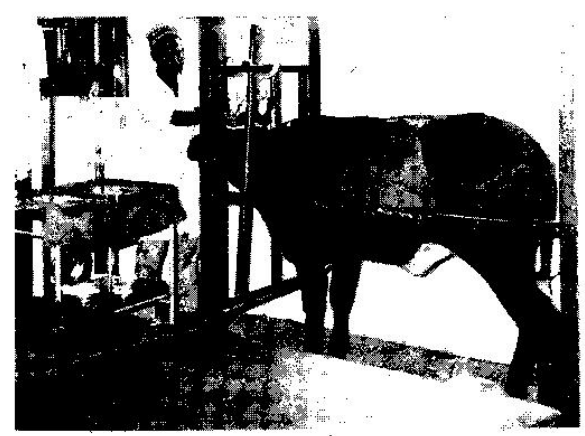

Plate 1

Preoperative restraint of cattle within an adjustable inetallic confinement.

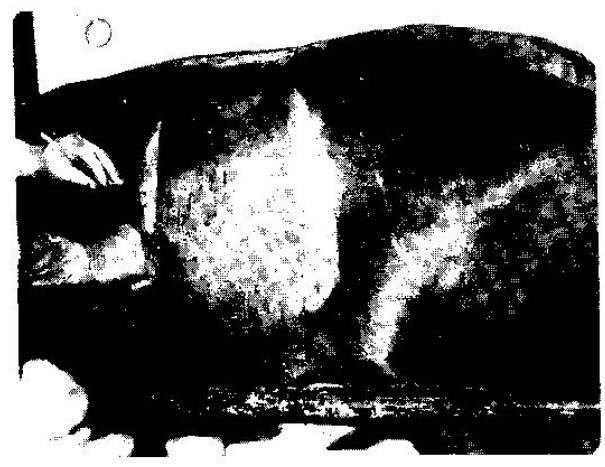

Plate 3

Faracostal incision technique. Note the - Lative position from the verteb al column and the hook bone.

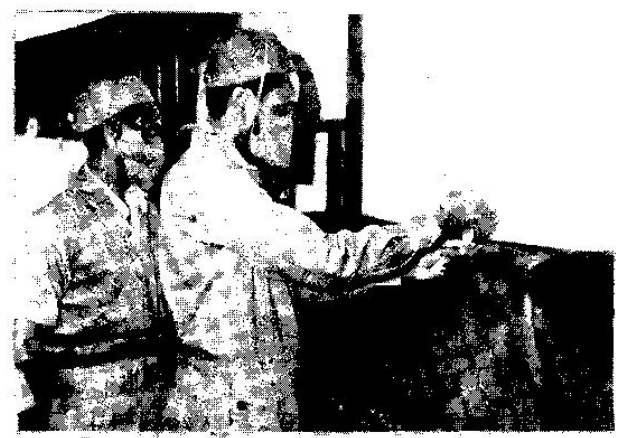

Plate 2

Paravertebral nerve blocks of thirteenth thoracic, first, second and third lumbar nerves.

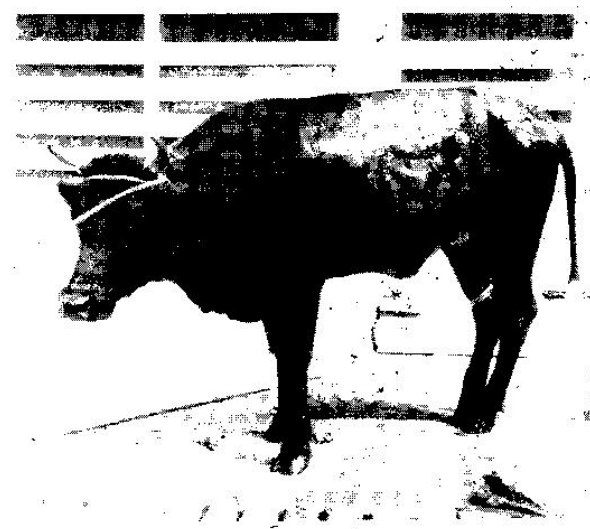

Plate 4

The fistulated cattle showing the relative position of the sutured incision and the exteriorized cannula. 
of the Department of Physiology, Rowett Research Institute and their staff for their various contributions.

The useful discussions with Dr. Akerejola of the Department of Veterinary Medicine, Ahmadu Bello University on the perspex type open fistula technique is also gratefully acknowledged.

\section{REFERENCES}

1. ASH, R.W. (1962). Gastrointestinal re entrant cannulae for studies of digestion in sheep. Anim. Prod. 4: 309-312.

2. COLIN G. (1886): Traite de Physiologie comparee des Animaux 3rd ed. vol. 1 Paris.

3. DIERNHOFER, K. (1928). Wien Tierarzt MSchr 15481.

4. DOUGHERTY, R.W. (1955) Permanent stomach and Intestinal Fistulae in ruminants some modification and simplification Cornell Vet 45.331. 357.

5. DOUGHERTY, R.W. and CELLO R.M (1952): Studies of the toxic factors in rumen ingesta of cows and sheep II Proc. 89th Ann meet. Am. Vet. Med. Ass. $p p 130$.

6. DOWNIE, H.G. (1954). Photokymo graphic Studies of regurgitation and relate phenomena in ruminants. Am. J. Vet Res. 15:217 223 .

7. MARKOWFTZ, J. (1954). In collabora-tion with J. ARCHIBALD and H.G. DOWNIE. Experimental Surgery, including surgical Physiology 3rd Ed. Baltimore Williams and Wilkins
8. MBA, A.U (1971). Evaluation of some Nigerian forages with African Dwarf goats. J.W. Afri. Sc. Ass. 16. 25.

9. MBA, A.U and OLATUNJI O. (1971). Studies on the ruminal VFA production in Zebu cattle and African dwarf goats W. Afri $J$ Biol \& Applied Chem. 14: 9-- 9 .

10. MBA, A.U., OKE, S.A. and OYENUGA, V.A. (1973). Studies on the in vitro and in vivo organic matter digestibility and Metabolizeable energy utilization in ruminants. Nig. Agric. J. 10 (1) 48-56

11. MCHENZIE, J.O. and KAY, R.NB (1968). Rumen cannulae made from vulcathrere $J$ S Sc. Technol. 14: 15-16.

12 OLUBAJO, F.O. and OYENUGA, V.A. (1970). Digestibility of tropical pastures using the indication technique J. Agric. Sc. 75: 175-181.

13. OLADOSU, L.A. and AKPOKODJE, $J U$ (1975): Rumen cannulation of the Red Sokoto (Maradi) Goats for Nutritional studies in Nigeria. Nig. J.Anim. Prod. 2. (2). 227-234.

14. PHILLIPSON, A.T, and INNES, J.R.M. (1939). Permanent stomach fistulae in ruminants. Quart. J. Exp. Physiol 29: $333-341$

15. SCHALK, A.F. and AlVADON, R.S (1928): N. Dak. Agric Exp. sta. Bull. No. 216.

16. TOPPS, J.H., KAY, R.N.B. and GOODALL, E.D. (1968): Digestion of concen trate and of hay in the stomach and intestine of ruminant Brit. J. Nutr 22: $261-279$. 